\title{
Late Holocene climatic events, the main factor of the cultural decline in North Central Iran during the Bronze Age
}

\author{
Babak Shaikh Baikloo Islam ${ }^{1}$, Ahmad Chaychi Amirkhiz ${ }^{2}$, and Kamal Al-Din Niknami 3 \\ 1 Department of History and Archaeology, Science and Research Branch, Islamic Azad University, Tehran, IR \\ babak.bagloo@srbiau.ac.ir \\ 2 Iranian Center for Archaeological Research, Research Institute of Cultural Heritage and Tourism, Tehran, IR \\ a.chaychi@richt.ir \\ 3 Department of Archaeology, University of Tehran, Tehran, IR \\ kniknami@ut.ac.ir
}

\begin{abstract}
During the Bronze Age, the cultural region of North Central Iran (NCI) suffered a longterm cultural decline, probably due to severe droughts. According to paleoclimate research, during the overall period c. 5.4-3.5 ka BP, four widely observable climatic events occurred at c. 5.3-5.0, 4.94.7, 4.2-3.9, and 3.8-3.5 ka BP, and these appear to have caused widespread environmental damage in the Near East. Archaeological evidence of the NCI-region reveals political events that can be associated with the observed climatic variability. Paleoclimate research and archaeological studies can attribute, in combination, the cultural decline of NCI during the Bronze Age to the Late Holocene climate change.
\end{abstract}

KEY WORDS - Bronze Age; Late Holocene; drought; North Central Iran; cultural decline

\section{Pozno holocenski podnebni dogodki kot poglavitni dejavniki kulturnega zatona $v$ severnem delu centralnega Irana v bronasti dobi}

\begin{abstract}
IZVLEČEK - V času bronaste dobe je prišlo na območju severnega dela centralnega Irana do dolgoročnega kulturnega zatona, ki so ga verjetno povzročila obdobja hude suše. Glede na paleoklimatske raziskave lahko prepoznamo štiri zelo izrazite podnebne dogodke v obdobju med ok. 5,4 in 3,5 tisoč let pred sedanjostjo (le-ti so: 5,3-5,0 tisoč let, 4,9-4,7 tisoč let, 4,2-3,9 tisoč let ter 3,8-3,5 tisoč let pred sedanjostjo), ki so povzročili razširjeno okoljsko škodo na Bližnjem Vzhodu. Arheološki zapisi $v$ tej regiji kažejo na politične dogodke, ki jih lahko povežemo s podnebno spremenljivostjo. S pomočjo paleoklimatskih in arheoloških raziskav lahko bronastodobni kulturni zaton na območju severnega centralnega Irana vežemo na pozno holocenske podnebne spremembe.
\end{abstract}

KLJUČNE BESEDE - bronasta doba; pozni holocen; suša; severni centralni Iran; kulturni zaton

\section{Introduction}

Large, abrupt, and widespread climate changes with major impacts have occurred repeatedly in the past, when the Earth system was forced across thresholds (Alley 2003; 2005). Climate change, whether as severe warming or cooling periods, is regularly associated with impacts such as droughts, dust storms, extreme rainfalls, and flood events. Throughout prehi- story, climate change was often a serious threat to human life, and even altered the course of history. Literature is replete with references showing, in particular, how periods of extended drought have resulted in food supply disruptions, famine, and massive migrations of people, as well as being associated with social conflicts and wars (Wilhite 1992.81-82). 
An increasing number of paleoclimate studies demonstrate that, in effect since the late $6^{\text {th }}$ millennium BP, the climate has become drier, and this development may have led to the long-term cultural decline that we can observe in the cultural region of North Central Iran (NCI) during the Bronze Age. On the other hand, an abrupt and rapid societal impact of climatic variability has also been observed in many regions of the Middle East, and in particular during the so-called $4.2 \mathrm{ka} \mathrm{BP}$ event, which is convincingly put forward as having caused, (1) the collapse of the Akkadian Empire in Mesopotamia (Cullen et al. 2000; Weiss 2016; Weiss et al. 1993), (2) the occurrence of the First Intermediate Period in Egypt (Bell 1971), as well as (3) the cultural transition of the Harappa culture to its period of post-urbanization in the Indus valley (Possehl 1997a; 1997b; 2000; Staubwasser et al. 2003). In the present paper, we show that both slow and rapid processes can be observed in many regions of Iran. According to available absolute dates, there is a cultural decline between the Iblis VI and Mashiz phases in Kerman (SE Iran), between Banish and Kaftari phases in Marvdasht Plain (S Iran), in eastern Susiana and Dehloran Plains (SW Iran) for c. 900 to 1500 years (Voigt, Dyson 1992.126-128), and also in North Central Iran (NCI) during the Bronze Age (Pollard et al. 2012; 2013). In all these regions, it is most likely the shortage of permanent water resources that will have been responsible both for the abrupt severity as well as the prolonged extension of the droughts, which would have regularly occurred during the climate change periods, often to such an extent as to

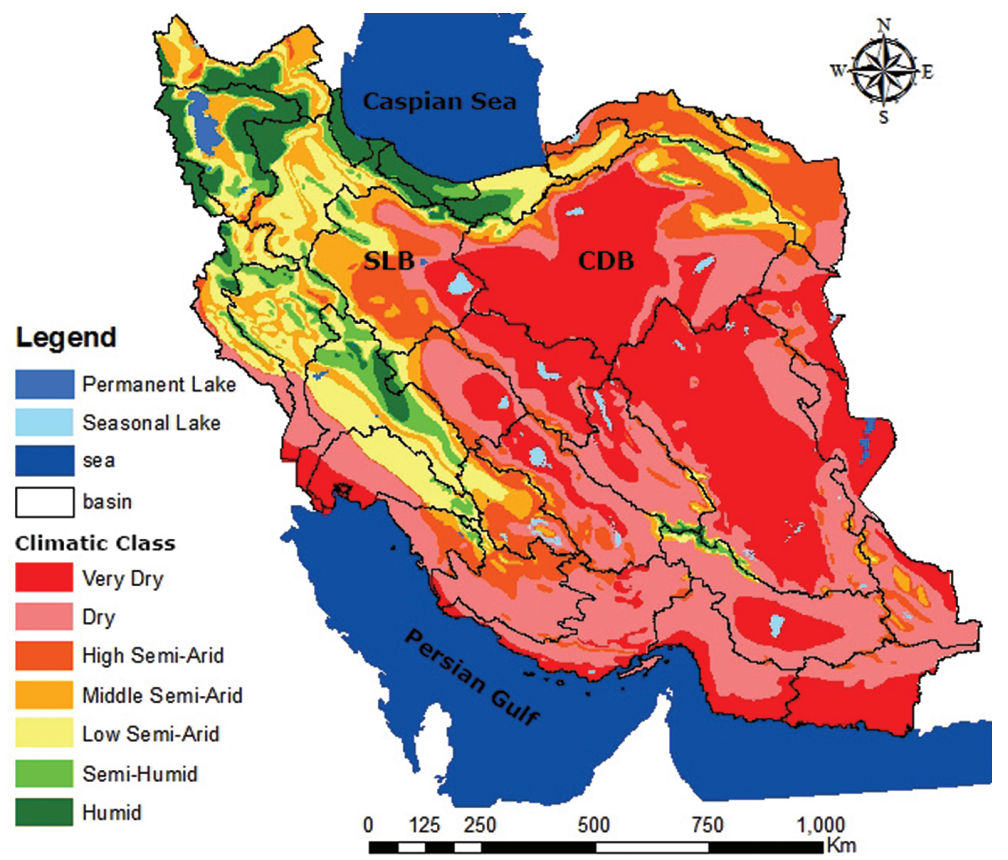

Fig. 1. Climatic classes and basins of Iran. inhibit the survival of human societies altogether. In consequence, the most appropriate archaeological model to assume (and therefore to study) is that during such periods many of the affected societies would either have migrated to more favourable regions, or alternatively have changed their subsistence systems from sedentary-farming to pastoralnomadism, whereby in both cases they will surely develop means for successful adaptive response to the changing environment (i.e. habitat tracking sen$s u$ Harvey Weiss [ref $e . g$. https://uispp2018.sciences conf.org/176190/document]).

\section{Geography and climate of Central Iran}

Apart from the northern and southern coastal regions of Iran, about $90 \%$ of the country's area is located on a plateau with an average elevation of $1000 \mathrm{~m}$ asl, and more than half of Iran is covered by mountainous and desert areas. The central Iran watershed is surrounded by the mountainous regions of Alborz, Zagros and eastern Iran, and includes 10 basins. The NCI cultural region covers the entire Salt Lake Basin (SLB) and the western part of the Central Desert Ba$\sin$ (CDB) (GOAF 2002). In this region, favourable agricultural fields are located in the plains and alluvial fans, and the rest is a dry and unproductive area (Fig. 1).

Due to the geographic situation of Iran in the subtropical region, it generally has semi-arid to arid environmental conditions. In the summer, the air temperature can rise to a maximum of $55^{\circ} \mathrm{C}$, and winter temperatures fall to a minimum of $-30^{\circ} \mathrm{C}$. About $23 \%$ of the total rainfall occurs in the spring, $4 \%$ in the summer, $23 \%$ in the autumn, and $50 \%$ in the winter (Frenken 2008. 185). The arrival of Mediterranean and North Atlantic low-pressure fronts into the continental climate of the Middle East causes winter precipitation (Alijani, Herman 1985). Annual rainfall in most parts of Iran is less than $100 \mathrm{~mm}$, and $75 \%$ of precipitation occurs in only $25 \%$ of the country's total area. Moreover, $75 \%$ of rainfall occurs when not needed by the agricultural sector (Madani 2014.316). The average annual precipitation in SLB is about $250 \mathrm{~mm}$ and in CDB is about $115 \mathrm{~mm}$. The long, permanent and freshwater rivers of these basins include the Jaj- 
roud, Karaj, Kordan, Khar, Ghara Chay and Qom in SLB, and Hableh and Cheshmeh Ali in CDB. Most prehistoric sites are located in SLB.

\section{Climate change}

What is termed 'climate' relates to temperature and precipitation conditions that are averaged over periods of 30 years or more. Climatic graphs show that the climate has been constantly changing, but we often apply the term 'climate change' only to climatic shifts that are experienced as unstable and unpleasant conditions that challenge our health and comfort.

The Holocene period began at $c .11 .7 \mathrm{ka} \mathrm{BP}$ after the end of the 2.5 million-year-old Pleistocene and coincides, on a larger time-scale, with the genesis of the Neolithic Age. Although the Holocene climate is not generally characterized by the extreme climate fluctuations of the last glacial period, it nonetheless shows significant variability (Anderson et al. 2007. 5). During the Holocene, with the occurrence of severe warming and cooling periods, climate conditions are known to have undergone frequent changes, and we may reasonably assume that they affected both nature and human cultures quite heavily.

The main causes for climate change include periodic changes in the Earth's orbit and axis, major variations in the thermohaline cycle, changing solar activity, and rise and fall of greenhouse gas emissions, including carbon dioxide, methane, nitrogen, water vapour, inter alia other mechanisms on different time-scales (cf. Denton, Karlén 1973; Mayewski et al. 1997; Bond et al. 2001; Anderson et al. 2007; Berger 2013). In combination with positive and negative feedback, i.e. amplification also on different time-scales, these changes can affect the Earth's climate over millennia and centuries. However, in archaeological studies we must also account for the existence of short-term weather oscillations, such as ENSO events (El Niño and La Niña), that occur on decadal time-scales (Philander 1989).

\section{Consequences of climate change}

Climate change, whether sudden or gradual, can have widespread and profound effects on nature (e.g., the physical and biological properties of the environment), but - and what complicates matters for cultural systems the induced impact is to some extent even more variable, since it depends strongly on complex and interrelated factors such as system pressure, adaptability, and survival strategies. In con- sequence, the cooling and warming events, each one occurring in some specific geographical position and latitude, will affect the environment in often complex manners, but most extremely by changes in humidity and temperature. However, perhaps the most fundamental changes occur in the livelihoods of all species, when the system temperature exceeds some specific threshold, above (or below) which the tolerance limits are overstretched and mortality increases.

In long response to severe, repeated, and abrupt climate changes, both individual humans as well as groups are equipped with a wide variety of adaptation and survival measures, including short- and long-distance movements in the landscape, as well as memory of the specific properties of these landscapes ( $c f$. transhumance and migration). Archaeological findings show, for example, that humans were capable of adapting to the extremely cold and dry climate of the Arctic during the Late Pleistocene c. $27 \mathrm{ka} \mathrm{BP}$ (Pitulko et al. 2004), just as they adapted to the arid conditions in the Thar (Enzel et al. 1999) and Sahara Deserts (deMenocal et al. 2000) in the Late Holocene (Gupta 2004; Zerboni et al. 2016). In other cases, however, it appears that civilizations collapsed as a result of climate change (Prentice 2009.2). With the recent increase in research interest on these topics it is becoming increasingly apparent that the relationship between humans, plants, animals and their joint environment is so highly diverse and variable that there is no simple correlation between climate change and human response (Petrie, Weeks 2018.302).

Climate change can, in several ways, affect human life and survival, and a list of the main factors and events that are associated with extreme weather events would include: heat waves, cold spells, torrential rainfalls, floods, droughts, sand and dust storms, hurricanes, regional food shortages, the outbreak of fatal diseases, civil conflict, war, migration and displacement (McMichael et al. 2006). According to historical documents, however, it is drought that can be identified as the main (immediate) cause of famine, malnutrition and increased mortality rates, although the impact of unfavourable climatic periods is practically always associated with the spread of infectious diseases such as plague, cholera, smallpox, and bloody diarrhoea (McMichael 2012). Psychological studies also show that a wide range of climate change outcomes can have adverse effects on people's mental health by causing disorders such as anxiety and depression (Trombley et al. 2017.4546; Frumkin et al. 2008.442). 


\section{Drought periods}

Drought indicates a lack of suitable rainfall during a long period of time, which leads to soil moisture loss due to high evapotranspiration and a reduction in runoff. In effect, drought disturbs the normal human and biological activities (Barry, Chorley 2009. 101). Drought is a creeping phenomenon, making an accurate prediction of either its onset or end a difficult task. Also, the impact of a drought depends largely on society's vulnerability to it at that particular moment (Wilhite, Glantz 1985.2-3). This phenomenon, like all environmental hazards, has a wide variety of natural and social dimensions. To begin, drought reduces the amount of water in the rivers, wetlands, and lakes, and is the biggest cause of destruction of forests and pastures. In the economy, its most devastating effects relate to agricultural production (Hejazizadeh, Javizadeh 2010.49-73). It is immediately obvious, therefore, why Iran - which is naturally a semi-arid and dry land - has in the past so often been affected by short- and long-term droughts. Iranian people have always been struggling with this natural challenge, such that, according to the inscription of Darius the Great (522-486 $\mathrm{BC})$, the phenomenon of drought has long been seen as a great enemy for Iranians (Sen 1941.91; see https://ia801606.us.archive.org/31/items/in.ernet. dli.2015.515396/2015.515396.0ld-Persian.pdf).

One of the most direct consequences of drought is that dust storms can seriously threaten the quality of life and health of the people. Climate has an important effect on the production, transfer and deposition of dust, but wind, dust and climate actually have an reciprocal relationship, since the atmospheric dust particles themselves directly and indirectly affect the climate, due to feedback processes (Goudie, Middleton 2006.45). Dust storms are powerful winds that affect vast areas. They can impact air quality, both on long and short time-scales, as well as local and global geographic dimensions (Schweitzer et al. 2018.36). In Iran, and mainly in its western, southwestern and southeastern regions, dust storms occur predominantly in the summer (Furman 2003.419420). In 2014 a massive dust-storm occurred in Tehran that caused considerable disturbance to the city, due to disrupted trees and fallen objects, including a number of fatal injuries. Such intense storms are also documented in the past, whereby archaeological and paleoclimate studies demonstrate their occurrence in parallel to drought events. An example is the collapse of the Akkad empire (2334-2155 BC), already mentioned above, that was affected not only by the extreme drought conditions during the $4.2 \mathrm{ka} \mathrm{BP}$ event, but also by severe dust storms. During the incident it appears that many inhabitants of the northern cities of Mesopotamia migrated to the south, where the massive population further disrupted the already critical economic and social situation (Weiss 2017; 2016; Weiss et al. 1993).

Extreme precipitation events, such as torrential rainfalls and floods, represent yet another feature of droughts. In dry periods, due to the decreasing precipitation and associated loss of vegetation, the terrestrial surface conditions are provided for an increase in flood events. In consequence, and perhaps unexpectedly, one of the best indicators for drought periods is the occurrence of severe periodic rainfalls, which lead to a high probability for the occurrence of huge and destructive floods (Maghsoudi, Mohammad Nejad 2011.50-53). The archaeological excavations at Mafin Abad and Meymanat Abad in Tehran province and at Ghara Tepe of Qom river in Qom province indicate that during droughts of the middle and late $6^{\text {th }}$ millennium BP these settlements were buried under flood sediments and abandoned forever (Shaikh Baikloo et al. in press; 2016).

\section{Climatic events during the Bronze Age}

The Bronze Age (c. 5.2-3.5 ka BP) coincided with the beginning of urbanization, the invention of writing techniques, the emergence of social complexities, and the formation of primitive states to advanced empires. In broader terms, this cultural period is contemporary with the late Middle Holocene and the early Late Holocene. According to paleoclimate research, since the $6^{\text {th }}$ millennium BP the climate generally shifted towards drier conditions (BarMatthews et al. 1997; Mayewski et al. 2004; Migowski et al. 2006; Sharifi et al. 2015) The studies reported here show that during the Bronze Age four climatic changes have occurred: (1) the $5.2 \mathrm{ka} \mathrm{BP}$ event $(c$. 5.3-5.0 ka BP) caused dry climatic conditions; (2) the $4.8 \mathrm{ka}$ BP event ( $c$. 4.9-4.7 ka BP) led to a cold climate; (3) the $4.2 \mathrm{ka}$ BP event $(c .4 .2-3.9$ ka BP) caused a megadrought (Weiss 2017; 2016; Weiss et al. 1993), and significant political-social events in the Middle East; (4) the most recent climate event during the Bronze Age occurred between 3.8 and $3.5 \mathrm{ka} \mathrm{BP}$, and although it is likely that this climate change was less severe than previous ones, it can be linked to socio-political events of this period.

\section{The 5.2 $\mathrm{ka} \mathrm{BP}$ event (c. 5.3-5.0 $\mathrm{ka} \mathrm{BP}$ )}

Based on the chrono-stratigraphy of the Greenland Ice Sheet Project 2 (GISP2), a warm-dry period oc- 
curred between $c .5 .3$ and $5.0 \mathrm{ka} \mathrm{BP}$ (Fig. 2) (Alley 2003; 2004a; 2004b). Also, the (presumably same) event at $5.2 \mathrm{ka} \mathrm{BP}$ has also been identified in Soreq Cave (Bar-Matthews et al. 2011), at Van Lake (Lemcke, Sturm 1997), the Gulf of Oman (Cullen et al. 2000), the Arabian Sea (Sirocko et al. 1993), and on Kilimanjaro (Thompson et al. 2006). Drought evidence between 5.5 and $4.9 \mathrm{ka} \mathrm{BP}$ is also reported from Mirabad Lake records (W Iran), where dry conditions are accompanied by an increase in oxygen isotopes, although similarly only coarsely dated to the $5.2 \mathrm{ka}$ BP event (Stevens et al. 2006; Jones et al. 2011.28). Paleoclimate records from Maharlou Lake (S Iran) also indicate dry conditions that date from c. $5.1 \mathrm{ka} \mathrm{BP}$ to the end of the $5^{\text {th }}$ millennium BP (Djamali et al. 2009.129-130), and studies at Arzhan Lake (S Iran) similarly illustrate an arid climate at c. 5.7-5.0 ka BP (Sadat Hoseini et al. 2016) (Fig. 3). At much higher dating resolution, and therefore more convincingly, the detailed dust-chronology from Lake Neor (NW Iran) suggests the pre-dominance of dry climatic conditions over the region since the $6^{\text {th }}$ millennium BP (Fig. 5b) (Sharifi et al. 2015). Records of Lake Xiaolongwan (E Asia) show a warm period between 5.2 and $4.9 \mathrm{ka} \mathrm{BP}$ (Fig. 4) (Xu et al. 2014). According to Shari Playa studies (central Iraq), there was a dry period between 5.2 and $4.8 \mathrm{ka} \mathrm{BP}$ (Jassim et al. 2007.8). Paleoclimate studies on AlHussaynia in the same region also indicate warmdry climatic conditions from $c .6$ to $3.5 \mathrm{ka} \mathrm{BP}(A l i$ 2014.595) (Fig. 3). Göl Hissar lake studies (SW Turkey) similarly determine that the climate has shifted to drier conditions since $c .5 .1 \mathrm{ka} \mathrm{BP}$ (Eastwood et al. 2007.327).

\section{The $4.8 \mathrm{ka}$ BP event (c. 4.9-4.7 ka BP)}

The GISP2 -stable-oxygen ice-core record indicates a significant drop in air temperature between $c .4 .9$ and $4.7 \mathrm{ka} \mathrm{BP}$, with a peak at $c .4 .8 \mathrm{ka} \mathrm{BP}$ (Fig. 2) (Alley 2004b.65). Reconstruction of Holocene climate by studies at Sjuodjijaure Lake (N Sweden) shows a decrease in temperature and progression of glaciers

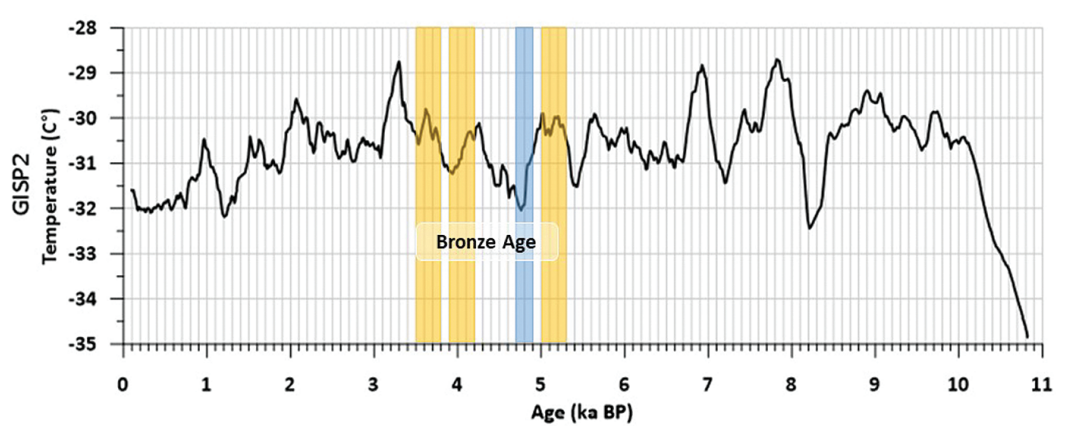

Fig. 2. Temperature changes in central Greenland during the Holocene Age based on GISP2 Proxy Temperature Data (Alley 2004). between 5.1 and $4.5 \mathrm{ka} \mathrm{BP}$ (Rosén et al. 2001.560). In the Baltic Sea basin, paleoclimate records show a two-stage air temperature decrease, the first at 5.0$4.5 \mathrm{ka} \mathrm{BP}$ and the second at 4.3-3.3 ka BP. Temperatures in the region started to drop at $c .5 .0-4.5 \mathrm{ka}$ cal BP, coincident with decreased summer solar insolation due to the quasi-cyclical changes in the Earth's orbit (Borzenkova et al. 2015.42-44). Paleoclimate records from Lake Xiaolongwan illustrate a cooling period during the first half of the $5^{\text {th }}$ millennium BP, with a peak at $c .4 .75 \mathrm{ka} \mathrm{BP}$ (Fig. 4) (Xu et al. 2014.5).

\section{The $4.2 \mathrm{ka}$ BP event (c. $4.2-3.9 \mathrm{ka} \mathrm{BP}$ )}

This climate change, identified as the $4^{\text {th }}$ climatic event of Bond in North Atlantic Basin (Bond et al. 1997; 2001), if only with medium dating resolution and unfortunately still not independently confirmed, apparently started at $4.2 \mathrm{ka} \mathrm{BP}$ and lasted for about 300 years. During this period a severe drought is visible almost everywhere in SW Asia (Weiss 2017). Given that the event has been recorded in more than 20 locations around the world, it is likely to have global character. However, at least at seven locations (British Columbia in W Canada, Spain, Ireland, Romania, and Namibia and Namib Desert in $S$ Africa), the event is documented as a wet event (Railsback et al. 2018. 79, Fig. 1). The GISP2 studies indicate a warming period, with a drop in humidity from around 4.3 to $4.1 \mathrm{ka} \mathrm{BP}$ (Fig. 2) (Alley $2004 b$. 65). Further evidence for a dry $4.2 \mathrm{ka} \mathrm{BP}$ event is indicated by the coincident dust-increase in the Gulf of Oman (Cullen et al. 2000), at Tecer Lake (Kuzucuoğlu et al. 2011), Soreq Cave (Bar-Matthews et al. 2011), the Dead Sea (Migowski et al. 2006), and to some extent also from Zazari Lake (Cavallari, Rosenmeier 2007). Further possible impacts of this event are reported from Egypt, with geomorphological studies carried out in Faiyum Lake (Hassan, Hamdan, 2008; Marks et al. 2018) and the Sakkara-Memphis flood plain (Hamdan et al. 2014). The core drilled near the shore of Faiyum Lake shows that there was an abrupt drop in water level as the lake almost desiccated. The Saqqara-Memphis core also indicates an event of low Nile flood as the valley dried out and aeolian sand encroached. Evidence suggests that the event caused the movement of sand dunes, the occurrence of sand and dust storms and severe damage of ancient Egyptian settlements (Hamdan et al. 2016.39). 


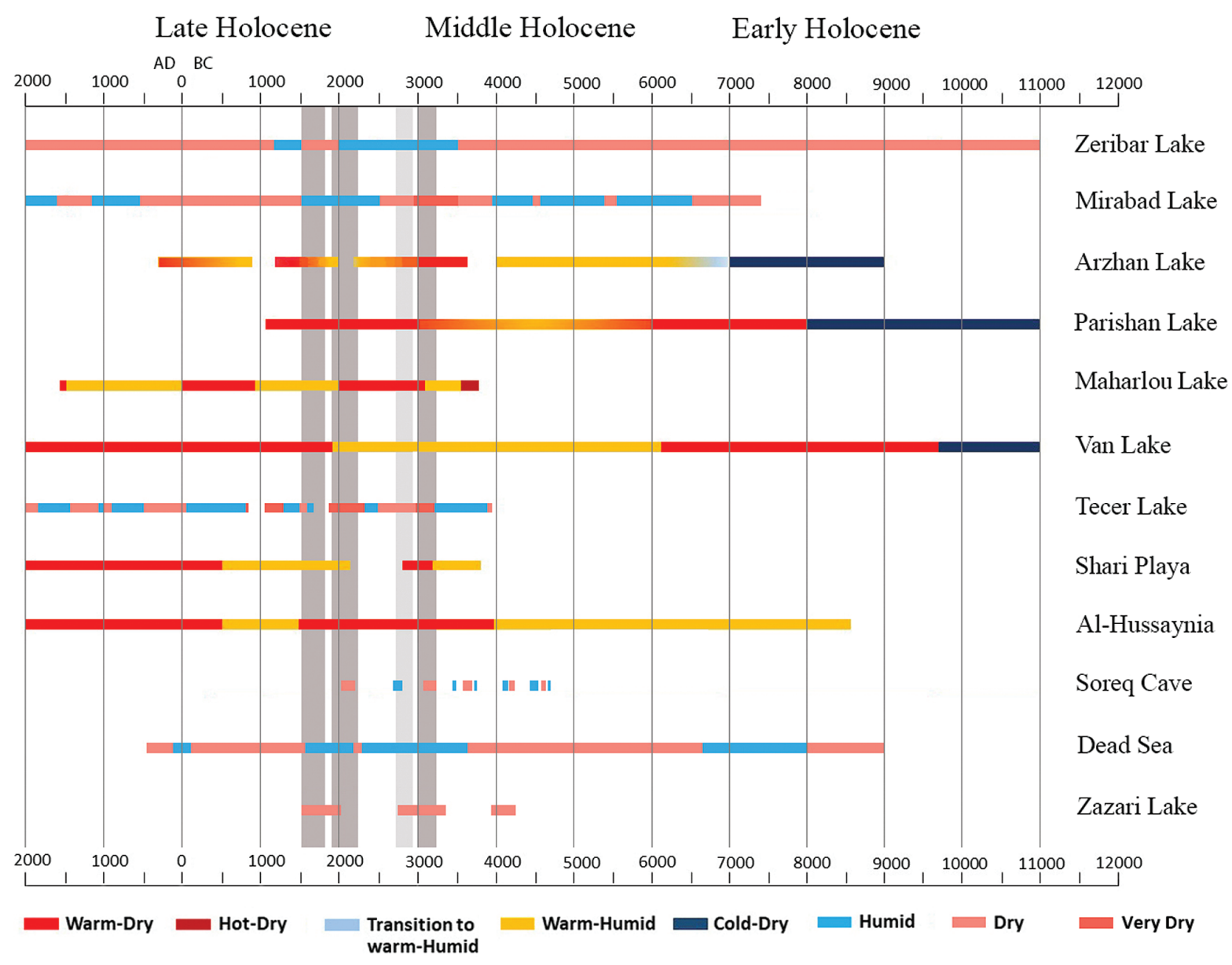

Fig. 3. The 13 000-year-old climatic condition based on paleoclimate studies in the Near East. Zeribar Lake (Stevens et al. 2001; Wasylikowa et al. 2006; Maghsoudi et al. 2014); Mirabad Lake (Stevens et al. 2006); Arzhan Lake (Sadat Hoseini et al. 2016); Parishan Lake (Davoudi et al. 2014); Maharlou Lake (Djamali et al. 2009); Van Lake (Wick et al. 2003); Tecer Lake (Kuzucuoğlu et al. 2011); Shari playa (Jassim et al. 2007); Al-Hussaynia (Ali 2014); Soreq Cave (Bar-Matthews et al. 2011); Dead Sea (Migowski et al. 2006); Zazari Lake (Cavallari, Rosenmeier 2007).

According to the Iranian research in Parishan Lake (W Iran) (Davoodi et al. 2014) and Maharlu Lake (Djamali et al. 2009), the climate was pre-dominantly warm-dry in this region during the $5^{\text {th }}$ millennium BP. The studies at Zeribar Lake studies (W Iran) also indicate a dry period between 4 and 3.5 ka BP (Stevens et al. 2001) (Fig. 3). Paleoclimate records from Lake Hamoun (SE Iran) (Fig. 5a) (Hamzeh et al. 2017), Lake Neor (Fig. 5b) (Sharifi et al. 2015), and Jazmurian Playa (SE Iran) (Fig. 5c) (Vae$z i$ et al. 2018) confirm the existence of geographically widespread dry conditions along with increasing dust flux during the $4.2 \mathrm{ka}$ BP event.

According to archaeological findings, as documented from many regions in the eastern Mediterranean, the Levant, and Mesopotamia, there was a significant decline in the number of settlements during the event (4.2-3.9 ka BP) (Staubwasser, Weiss 2006. 381 ). In the Levant, the $4.2 \mathrm{ka}$ event is associated with a $20-30 \%$ reduction in annual rainfall (BarMatthews et al. 1997), which would have seriously disturbed the subsistence system of farmer societies, and which is indeed indicated with only a few settlements remaining in close vicinity to surface water (Dever 1995; Palumbo 2001). We may expect a similar situation to have occurred throughout western Syria and the middle Euphrates. According to available palaeo-rainfall modelling studies, the $\mathrm{Ha}$ bur Plains in the North of Mesopotamia (NE Syria) must have dried up, with dust storms causing such a wide spectrum of economic and social problems for the population that the proposed abandonment of more than $70 \%$ of cities in the region is indeed plausible. Ultimately, of course, it is not only drought that caused the collapse of the Akkad dynasty, but the direct combination of drought with related factors such as decreasing agricultural production, social implosion, internal riots and foreign attacks. After the fall of the Akkad, the region was similarly 
rapidly re-settled at $c$. $3.9 \mathrm{ka} \mathrm{BP}$ (Weiss 2017; 2016; Weiss et al. 1993). Cultural responses to the $4.2 \mathrm{ka}$ BP are also widely observed in the Harappa civilization, and in particular around the Indus Valley to Makran and north-western India. For example, from the late $5^{\text {th }}$ millennium BP to the early $4^{\text {th }}$ millennium BP, the impressive baths and cereal warehouses in Mohenjo-Daro were abandoned, and the settlement system in the Indus Valley, the Indus-Sarasvati Valley and the Baluchi heights declined (Possehl 1997a; 1997b; 2000).

\section{The warming event of $c .3 .8-3.5 \mathrm{ka} \mathrm{BP}$}

This specific event coincides with the Second Intermediate Period in the Egyptian Empire at $c$. 3.65$3.55 \mathrm{ka} \mathrm{BP}$ (Ryholt 1997), and the end of the first Dynasty in Babylonia, which is related to attacks by the Hittites at c. $3.6 \mathrm{ka}$ BP (Roebuck 1960). GISP2 studies (Alley 2004a) indicate a warming period from $c .3 .8$ to $3.5 \mathrm{ka} \mathrm{BP}$ (Fig. 2). Paleoclimate records from Lake Hamoun (Fig. 5a) (Hamzeh et al. 2017), Lake Neor (Fig. 5b) (Sharifi et al. 2015), and Jazmurian Playa (Fig. 5c) (Vaezi et al. 2018) suggest a dry period with increasing dust flux during the warming event. Zazari Lake studies also illustrate a drought period between 4.05 and $3.5 \mathrm{ka} \mathrm{BP}$ (Cavallari, Rosenmeier 2007). Although studies of Zeribar Lake (Stevens et al. 2001), Parishan Lake (S Iran) (Davoudi et al. 2014), al-Hussaynia (Ali 2014.595), and Van Lake (Wick et al. 2003) are suggestive of a warm-dry climate at this time, the equally comprehensive paleoclimate research at Mirabad Lake (Stevens et al. 2006) and Maharlou Lake (Djamali et al. 2009) indicates a warm-humid climate. The existence of a humid period between 4.1 and 3.5 $\mathrm{ka} \mathrm{BP}$, followed by a long-term dry period, is comparatively well-documented in the Dead Sea Levels (Migowski et al. 2006.427) (Fig. 3).

\section{The Bronze Age in NCI}

Just as in wider regions of the eastern Mediterranean and the Near East, in Iran (and more specifically NCI) the Bronze Age coincides with the beginning of the Late Holocene. Again, it is important to note what the paleoclimate records indicate, namely, beginning with the $6^{\text {th }}$ millennium BP a general development towards increasingly drier conditions, on top of which there is evidence for severe and prolonged droughts. From the Late Chalcolithic Age to the Early Bronze Age (c. $5.4-4.7 \mathrm{ka} \mathrm{BP}$ ), most of the human settlements in NCI were gradually abandoned, and a period of cultural decline lasted throughout the Bronze Age. Only a few settlements near Damghan appear to have been re-established, after about 600 years, and the absolute dates suggest a settlement gap between the Hissar II and III phases at c. 5.0-4.4 ka BP. About two centuries later, Hissar III ended at $2170 \mathrm{cal} \mathrm{BC}$ (Voigt, Dyson 1992.128, Tab. 1). It is worth noting that, based on the similarities of the material culture of Hissar III and Tourang Tepe III $_{C}$, the authors (Voigt, Dyson 1992) have increased the end of Hissar III culture up to $1900 \mathrm{cal} \mathrm{BC}$. However, given the completely different climates of the Gorgan and Damghan areas, it seems that with the beginning of the $4.2 \mathrm{ka}$ BP dry event (c. $4.2-3.9 \mathrm{ka} \mathrm{BP}$ ) the phase of Hissar III in Damghan started to decline at the time of its maximum height (4.2-4.1 ka BP). Therefore, these two cultures did not have a long-term overlap. Thereafter, the cultural decline continued up to the Iron Age. During this period, the settlements appear to have shifted to the Gorgan Plain (Fig. 6) and other southern areas of the Caspian Sea.

On the Qazvin Plain the settlement at Tepe Ghabristan finally ended at the end of the Early Bronze Age (2700 cal BC). However, Tepe Shizar and Tepe Sagza-

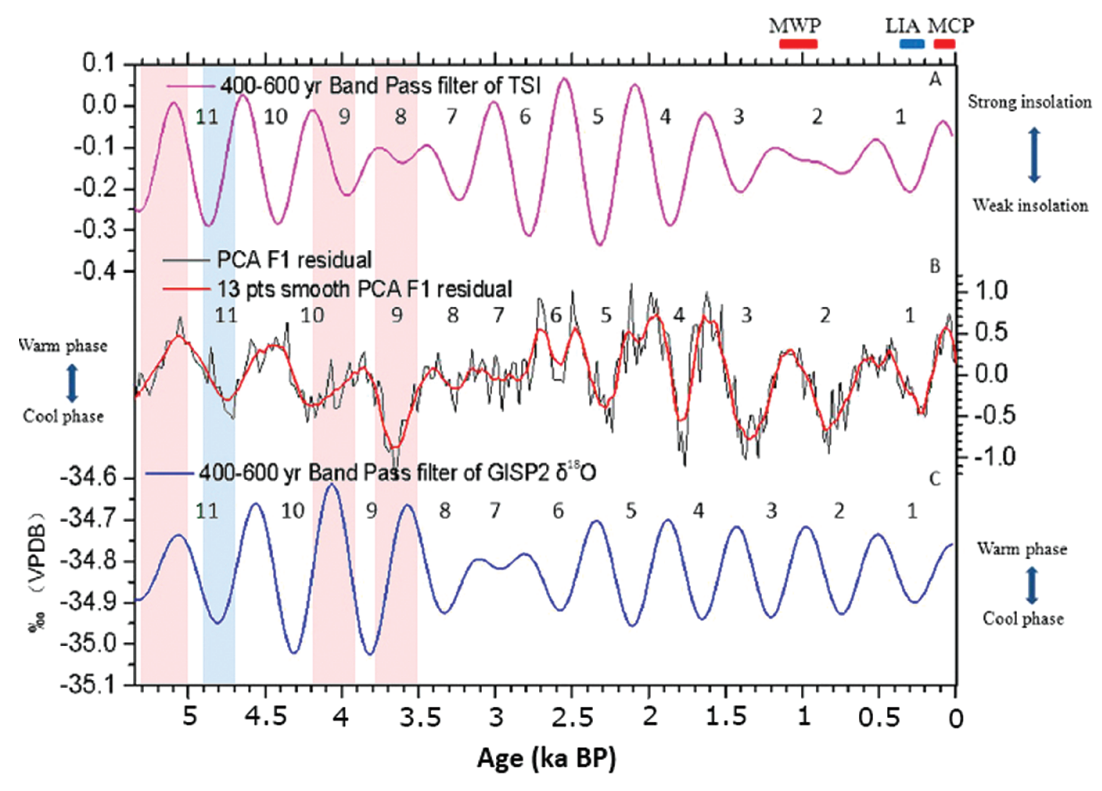

Fig. 4. A comparison of climate proxy records from core Lake Xiaolongwan with other proxy records for Total Solar Irradiance and Greenland (GISP2) oxygen isotope ( ${ }^{180}$ ). A 400-600-year band pass filter of Total Solar Irradiance; B Residuals of PCA F1; C 400-600-year band pass filter of GISP2 oxygen isotope ( ${ }^{180}$ ) (Xu et al. 2014.5, Fig. 6). 
bad have layers belonging to the Middle Bronze Age. Tepe Shizar, after a settlement period in the Chalcolithic Age, was re-settled at 2860-2450 cal BC. Again following a gap (2450-1880 cal BC), the site of Tepe Shizar was re-settled at $1880 \mathrm{cal} \mathrm{BC}$, and lasted until the Late Bronze Age or maybe even longer, into the Iron Age (Pollard et al. 2012. 115-116, 148, Tab. 16; Pollard et al. 2013.45, Tab. 9). Tepe Sagzabad was established in the Chalcolithic Age (3670-3540 cal BC), and was then, after a long gap, re-setthed at $1780-980 \mathrm{cal} \mathrm{BC} \mathrm{(Pol-}$ lard et al. 2012.116-119, 148, Tab. 16; 2013.45, Tab. 9).

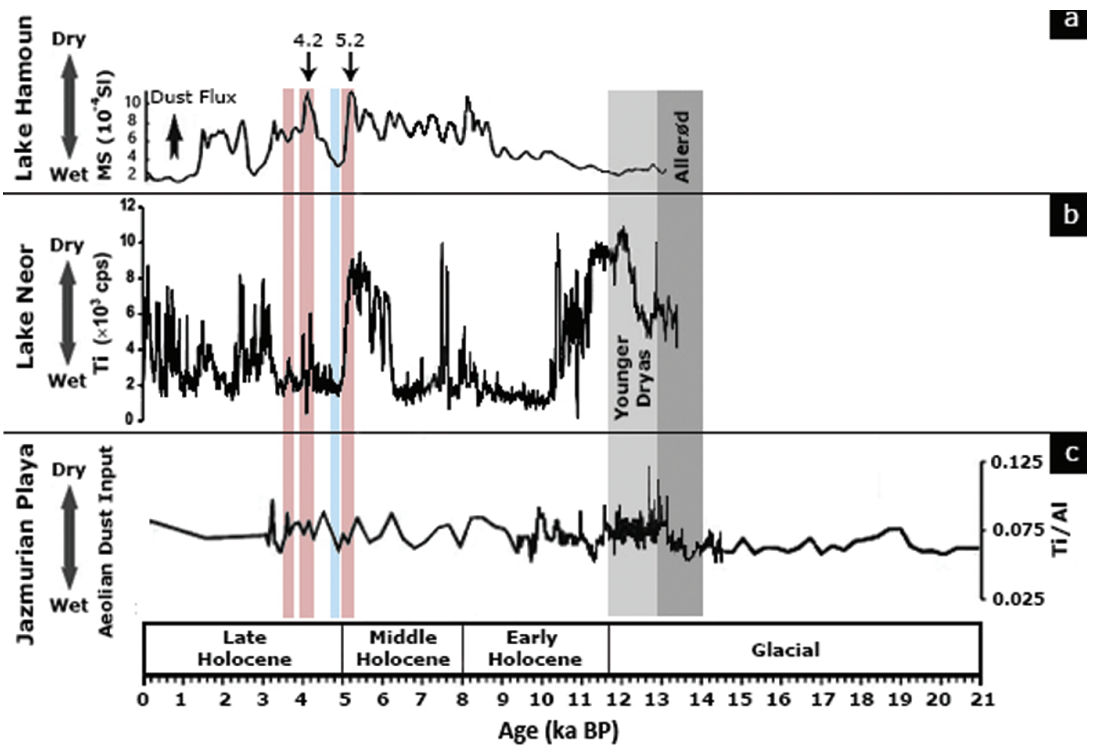

Fig. 5. a Diagram of dust flux from Lake Hamoun in SE Iran (Hamzeh et al. 2017.17, Fig. 6); b Variations of the Titanium (by the XRF analysis) from Lake Neor in NW Iran (Sharifi et al. 2015.222, Fig. 4); c Elemental ratios Titanium/Aluminium from Jazmurian Playa in SE Iran (Vaezi et al. 2018.17, Fig. 5).

Tepe Gholi Darvish in Qom, following a decline at 3000 cal BC, was re-settled at 2090-1860 cal BC. It is unclear at what time the next settlement began, but it ended at $1680 \mathrm{cal} \mathrm{BC}$, and was again re-settled at $1530 \mathrm{cal} \mathrm{BC}$. The end of this settlement period is not well defined (Pollard et al. 2013.45, Tab. 9). On the basis of the available dates, we may speculate that the settlement gaps coincide with the peak of droughts, but which are themselves not precisely dated (Fig. 7). It is nevertheless conspicuous that, when comparing the above-mentioned settle-

ments, almost all of the ancient sites in NCI declined at c. 5.2-4.8 ka BP (Fig. 8), following which the entire NCI cultural region fell into a long dark period which lasted until the $2^{\text {nd }}$ half of the $4^{\text {th }}$ millennium BP (Shaikh Baikloo et al. 2016).

\section{Migration to the Gorgan Plain}

The Gorgan Plain, located in the north of Alborz Mountains, is influenced by the Caspian climate and has a higher humidity than NCI. Studies of the Cas-

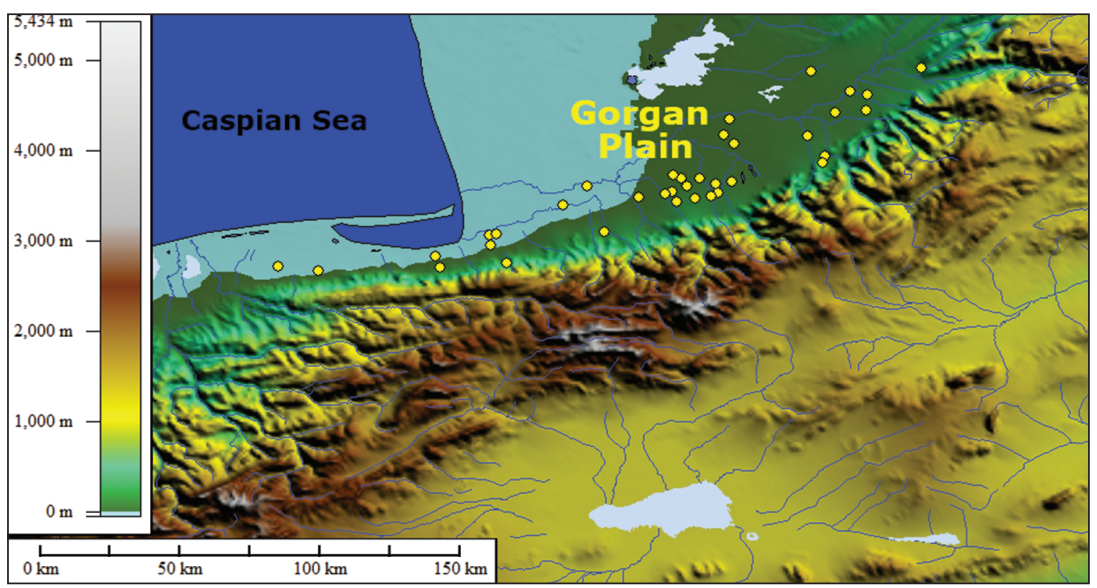

Fig. 6. Settlements of the Gorgan Plain from the second half of the $6^{\text {th }}$ millennium BP to the middle of the $5^{\text {th }}$ millennium BP. It should be noted that the number of sites found during archaeological surveys is more than this number, but the author's access to all reports was not possible. However, the high density of these sites clearly indicates a significant increase in human populations in this area between 5.4 and $4.5 \mathrm{ka} \mathrm{BP}$. In this map, the shorter and approachable mountainous communication paths between the northern and southern parts of Alborz are clearly visible. pian Sea level (CSL) during the Holocene Age show a gradual decline since the middle $6^{\text {th }}$ millennium BP, so that at the beginning of the Bronze Age CSL was lower than today's level, and this situation continued until the early $4^{\text {th }}$ millennium BP (Richagov 1997.171, Fig. 5). This suggests that drought periods, despite the wetter climate of the Gorgan Plain, have also affected this region. It should be further noted that the water level of this large lake depends on the inputs of the Volga River, which originates from Polar Regions. Therefore, it is plausible that the cooling conditions that pre- 
vailed during the early $5^{\text {th }}$ millennium BP, might have led to a decrease in CSL (Fig. 9).

The density and height of the Alborz Mountains in the south of the Gorgan Plain is lower than the other parts, so that the situation allows for easy passage from the southern part to the north.

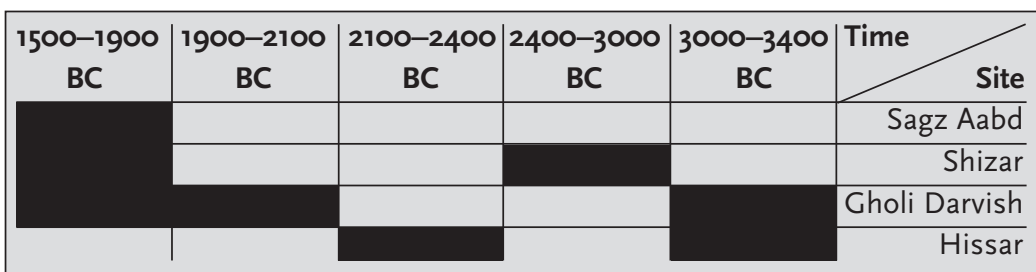

Fig. 7. The chronology of NCI from the Late Chalcolithic to the Early Bronze Age, based on absolute dates $\left({ }^{14} \mathrm{C}\right)$ of archaeological sites. The black colour represents a cultural gap.

Considering the revision of the relative dates of the Chalcolithic-Bronze settlements in the Gorgan Plain (Shaikh Baikloo 2018.298-330), which indicates a population growth trend since the second half of the $6^{\text {th }}$ millennium BP, along with a decrease in population in NCI and the decline of CSL, it can be assumed that with the intensification of drought the Gorgan Plain may have become more attractive for the settlement of farmer communities, and would

also have represented a desirable destination for the migration of people affected by drought and famine (Figs. 2, 3).

\section{Conclusion}

The Late Holocene was generally a period with increasingly low humidity, accompanied by frequent and prolonged droughts. Based on recent paleocli-

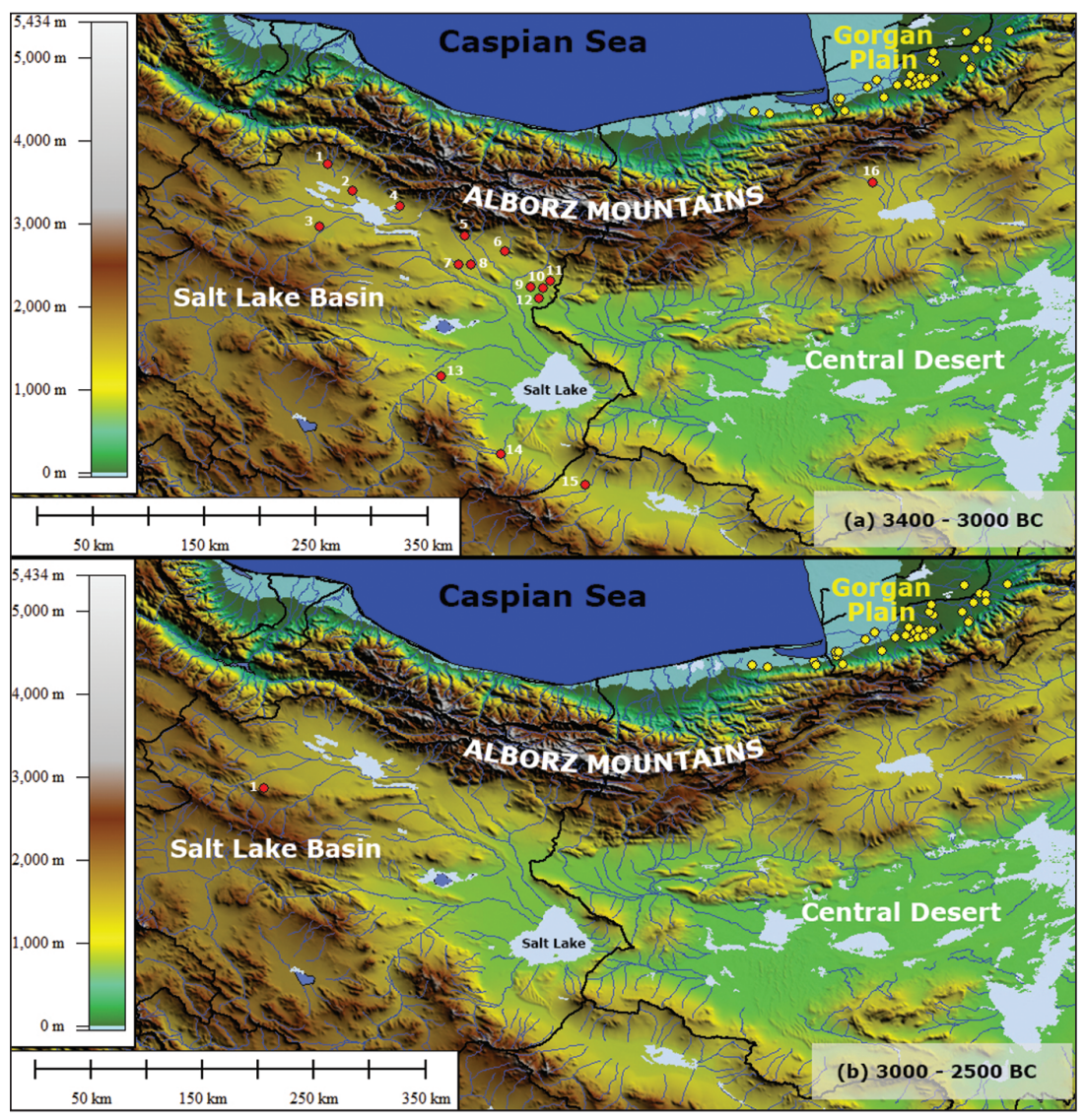

Fig. 8. a 1 Ismael abad, 2 Miyanpalan, 3 Ghabristan (Fazeli 2006); 4 Ozbeki (Majidzadeh 2010); 5 Kavousiya (Mosadeghi 2001); 6 Cheshmeh Ali (Fazeli et al. 2004); 7 Farhangian (Adibzadeh et al. 2014); 8 Meymanat abad (Yousefi Zoshk et al. 2015); 9 Chaltasian (Yousefi Zoshk 2012); 10 Sofalin (Hessari 2011); 11 Shoghali (Hessari et al. 2007); 12 Zavarvar (Ghasemi 2013); 13 Gholi Darvish (Sarlak 2011); 14 Sialk (Ghirshman 1938); 15 Arisman (Vatandoust et al. 2011); 16 Hissar (Schmidt 1937; Dyson, Howard 1989). b 1 Shizar (Valipour 2006). Decreasing the number of NCI settlements from the Late Chalcolithic to the Early Bronze Age and simultaneously increasing the Gorgan Plain settlements. mate research, in the timespan from the late $6^{\text {th }}$ millennium $\mathrm{BP}$ to the middle $4^{\text {th }}$ millennium BP, a total of four climatic changes are identifiable, with the first three as follows: (1) the $5.2 \mathrm{ka}$ BP dry event (c. 5.3-5.0 ka BP); (2) the $4.8 \mathrm{ka}$ BP cooling event (c. 4.9-4.7 ka BP); and (3) the $4.2 \mathrm{ka}$ BP hyper dry event (c. 4.2-3.9 ka BP); some studies have shown this event to be very wet. Also, according to Bond's research in the North Atlantic, the $4.2 \mathrm{ka}$ BP event was not only associated with cooling. Ice-core research in Greenland confirms it was a warm event. Despite some few remaining discrepancies of this kind, there can be little doubt concerning the global character of the $4.2 \mathrm{ka} \mathrm{BP}$ event, at least in the N-Hemisphere. In the present paper, looking from the perspective of Iran, we can readily confirm that the observed widespread settlement abandonment, and the many postulated regional and supra-regional migrations during the time of the $4.2 \mathrm{ka}$ event, were likely to have a direct causal back- 


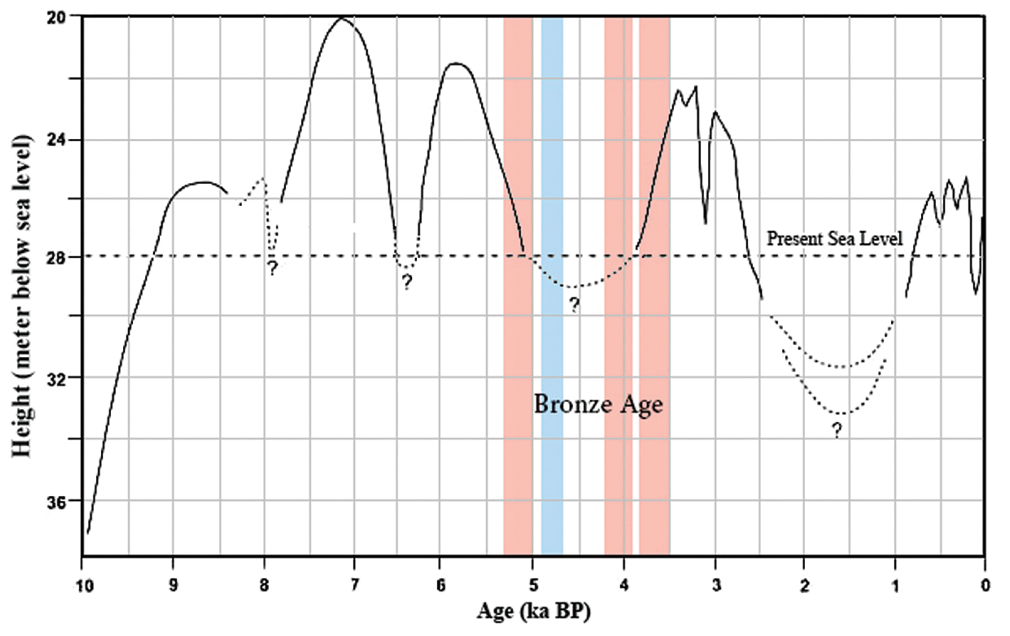

Fig. 9. The fluctuation of the Caspian Sea Level during the Holocene (Rychagov 1997.171, Fig. 5).

ground in the occurrence of severe droughts and dust storm, in many parts of the eastern Mediterranean, the Near East, as well as in the Middle East. Although there are remaining doubts as to the actual severity and the geographic extension of the $4.2 \mathrm{ka}$ event, and there are many societal details yet to be analysed if not discovered, we see no reason to exclude the hypothesis that the $4.2 \mathrm{ka} \mathrm{BP}$ event (in particular, the associated droughts and duststorms) was the underlying cause for the collapse of the Akkad Empire. And finally, with regard to our fourth climatic change, for similar reasons we expect that the 3.8-3.5 ka BP warm-dry event, although much less equally established, was to some extent also responsible for a number of socio-political events in Egypt and Mesopotamia, at this time.

As applies specifically to NCI, this is a naturally semiarid and dry region, that faced so many severe environmental challenges during periods of extended drought, that ultimately - in the course of the Holocene - it appears to have lost much of its early attraction for rural societies. Although surely only under longer-term (millennial/centennial) conditions, it is quite likely that many (real or potential) inhabitants of this region were finally so perturbed by the disruptive results of drought and famine that they preferred to occupy more favourable (wetter) areas, such as the Gorgan Plain in the Caspian Sea Basin. We may assume that any larger scale migrations would have taken the approachable mountainous communication paths in the north of Damghan.

Nevertheless, despite some interruptions there is strong evidence for the continuing cultural evolution of societies in NCI, throughout the region, from the Late Neolithic to the Late Chalcolithic. This trend, however, stopped at the peak of the increasing social complexity of the late $6^{\text {th }}$ millennium $\mathrm{BP}$, and did not lead to the genesis of urban societies and governments.

We thus propose, for good reasons, that the prevailing drought conditions in NCI may now be considered the main factor of this cultural decline, and in future studies we will aim to identify the actual (internal) stimuli for the observed societal response towards climate change. Given the fact that the formation of urban or state societies requires an increase in population and expansion of settlement centres, the requirements for vital and environmental facilities will increase and become more complex, such that the mere impact of cultural variables or growth of technological factors cannot be expected, in isolation, to bring these societies to the stage of urbanization. At the end of the Chalcolithic Age, the still continuing increase and indeed the regional maximum in population and essential bioresources appear to have coincided with the $5.2 \mathrm{ka}$ BP dry event, following which the environmental contexts necessary for the formation of urban and state societies have disappeared. Due to the environmental limitations of NCI, in this region there has never been a further spread of settlements, and population increase, as can be observed in the southern regions of Iran. In conclusion, and if only for climatic and environmental reasons, it is not expected that - following the Late Chalcolithic - the cultural development of this specific part of Iran would be similar to that in Mesopotamia, Egypt and the Indus Valley.

\section{ACKNOWLEDGEMENTS}

Many thanks to Dr. Hamidreza Valipour for promoting this article. We also wish to thank Professor Harvey Weiss and Professor Tony McMichael - may God bless him - for their valuable articles on the impacts of climate change. 


\section{References}

Adibzadeh M., Nemati M. R., and Mortezaie M. 2014. The results of excavation at the Robat Karim Hospital erea, near the Ancient site of Siah Ab (Farhangian). In Reports of the 13th Annual Archaeological Congress of Iran. Cultural Heritage Organization. Tehran: 39-44. (in Persian)

Ali M. O. 2014. Palynological evidences on paleoclimate and paleoenvironmental changes during Holocene of AlHussaynia District, Central Iraq. Arabian Journal of Geosciences 7(2): 589-595.

Alijani B. Harman J. R. 1985. Synoptic climatology of precipitation in Iran. Annals of the Association of American Geographers 75(3): 404-416.

https://doi.org/10.1111/j.1467-8306.1985.tb00075.x

Alley R. B. 2004a. GISP2 ice core temperature and accumulation data. IGBP PAGES/World Data Center for Paleoclimatology Data Contribution Series 13.

2004b. Abrupt climate change. Scientific American 291(5): 62-69.

Alley R. B., Marotzke J., Nordhaus W. D., Overpeck J. T., Peteet D. M., Pielke R. A., Pierrehumbert R. T., Rhines P. B., Stocker T. F., Talley L. D., and Wallace J. M. 2003. Abrupt climate change. Science 299(5615): 2005-2010. https://science.sciencemag.org/content/299/5615/2005

Anderson D. G., Maasch K. A., Sandweiss D. H., and Mayewski P. A. 2007. Climate and culture change: exploring Holocene transitions. In D. G. Anderson, K. A. Maasch, and D. H. Sandweiss (eds.), Climate Change and Cultural Dynamics. Academic Press. New York: 1-23.

Bar-Matthews M., Ayalon A. 2011. Mid-Holocene climate variations revealed by high-resolution speleothem records from Soreq Cave, Israel and their correlation with cultural changes. Holocene 21: 163-171.

https://doi.org/10.1177/0959683610384165

Bar-Matthews M., Ayalon A., and Kaufman A. 1997. Late quaternary paleoclimate in the eastern Mediterranean region from stable isotope analysis of speleothems at Soreq Cave, Israel. Quaternary Research 47: 155-168. https://doi.org/10.1006/qres.1997.1883

Barry R. G., Chorley R. J. 2009. Atmosphere, weather and climate. Routledge. New York.

Bell B. 1971. The dark ages in ancient history. I. The first dark age in Egypt. American Journal of Archaeology 75 (1): $1-26$.

Berger A. L. 1978. Long-Term Variations of Caloric Insolation Resulting from the Earth's Orbital Elements 1.
Quaternary research 9(2): 139-167.

https://doi.org/10.1016/0033-5894(78)90064-9

Bond G., Kromer B., Beer J., Muscheler R., Evans M. N., Showers W., Hoffmann S., Lotti-Bond R., Hajdas I., and Bonani G. 2001. Persistent solar influence on North Atlantic climate during the Holocene. Science 294(5549): 2130 2136. https://doi.org/10.1126/science.1065680

Bond G., Showers W., Cheseby M., Lotti R., Almasi P., deMenocal P., Priore P., Cullen H., Hadjas I., and Bonani G. 1997. A pervasive millennial scale cycle in North Atlantic Holocene and glacial climates. Science 278: 1257-1265. https://doi.org/10.1126/science.278.5341.1257

Borzenkova I., Zorita E., Borisova O., Kalnina L., Kisielienė D., Koff T., Kuznetsov D., Lemdahl G., Sapelko T., Stančikaitè M., and Subetto D. 2015. Climate change during the Holocene (past 12000 years). In H. J. Bolle, M. Menenti, and S. I. Rasool (eds.), Second Assessment of Climate Change for the Baltic Sea Basin. Springer International Publishing: 25-49.

Cavallari B. J., Rosenmeier M. F. 2007 December. A multi-proxy paleoclimate record of rapid Holocene climate variability from northern Greece/Greek Macedonia. In American Geophysical Union. Fall Meeting 2007. Abstract id. PP31A-0180.

Davoudi M., Azizi G., Maghsoudi M. 2014. Reconstruction of Holocene Climate Change in Southern Zagros: Evidence of Pollenology and Charcoal in Parishan Lake Sediments. Quantitative Geomorphology Researches (1): 65-79. (in Persian)

DeMenocal P., Ortiz J., Guilderson T., Adkins J., Sarnthein M., Baker L., and Yarusinsky M. 2000. Abrupt onset and termination of the African Humid Period: rapid climate responses to gradual insolation forcing. Quaternary science reviews 19(1-5): 347-361. https://doi.org/10.1016/S0277-3791(99)00081-5

Denton G. H., Karlén W. 1973. Holocene climatic variations - their pattern and possible cause. Quaternary Research 3(2): 155-205.

https://doi.org/10.1016/0033-5894(73)90040-9

Dever W. G. 1995. Social structure in the Early Bronze IV period in Palestine. In T. E. Levy (ed.), The Archaeology of Society in the Holy Land. Leicester University Press. London: 282-296.

Djamali M., De Beaulieu J. L., Miller N. F., Andrieu-Ponel V., Ponel P., Lak R., Sadeddin N., Akhani H., and Fazeli H. 2009. Vegetation history of the SE section of the Zagros Mountains during the last five millennia; a pollen record 
from the Maharlou Lake, Fars Province, Iran. Vegetation History and Archaeobotany 18(2): 123-136. https://doi.org/10.1007/s00334-008-0178-2

Dyson R. H., Howard S. M. 1989. Tappeh Hesār: Reports of the Restudy Project, 1976. Casa editrice le lettere. Firenze.

Eastwood W. J., Leng M. J., Roberts N., and Davis B. 2007. Holocene climate change in the eastern Mediterranean region: a comparison of stable isotope and pollen data from Lake Golhisar, southwest Turkey. Journal of Quaternary Science 22(4): 327-342.

https://doi.org/10.1002/jqs.1062

Enzel Y., Ely L. L., Mishra S., Ramesh R., Amit R., Lazar B., Rajaguru S. N., Baker V. R., and Sandler A. 1999. High-resolution Holocene environmental changes in the Thar Desert, northwestern India. Science 284(5411): 125-128. https://doi.org/10.1126/science.284.5411.125

Fazeli H. 2006. The Archaeology of Qazvin Plain from the $6^{\text {th }}$ millennium to first millennium BCE. Tehran University Publishers. Tehran. (in Persian)

Frenken K. 2009. Irrigation in the Middle East region in figures AQUASTAT Survey-2008. Water Reports (34). Food and Agriculture Organization of the United Nations (FA0). Rome.

Frumkin H., Hess J., Luber G., Malilay J., and McGeehin M. 2008. Climate change: the public health response. American journal of public health 98(3): 435-445. https://doi.org/10.2105/AJPH.2007.119362

Furman H. K. H. 2003. Dust storms in the Middle East: sources of origin and their temporal characteristics. Indoor and Built Environment 12(6): 419-426. https://doi.org/10.1177/1420326X03037110

Ghirshman R. 1938. Fouilles de Sialk, près de Kashan 1933, 1934, 1937. Vol. 2. Série archéologique. Musée du Louvre. Département des antiquités orientales. Tome 5. Libr. orientaliste Paul Geuthner.

GOAF 2002. The Gazetteer of Rivers in the Islamic Republic of Iran: Central Iran Watershed. Geographic Organization of the Armed Forces. Tehran. (in Persian)

Goudie A. S., Middleton N. J. 2006. Desert dust in the global system. Springer Science and Business Media. Heidelberg.

Gupta A. K. 2004. Origin of agriculture and domestication of plants and animals linked to early Holocene climate amelioration. Current Science-Bangalore 87: 54-59.
Hamdan M. A., Hassan F. A., Flower R. J., and Ebrahim E. M. 2016. Climate and Collapse of Egyptian Old Kingdom: A Geoarchaeological Approach. In Archaeology and Environment. Understanding the Past to Design the Future, a Multidisciplinary Approach. Proceedings of the International Workshop "Italian Days in Aswan", 16th18th November. CNR Edizioni. Rome: 89-100.

Hamdan M. A., Martinez S. M., Garcia Valles M. T., Nogués J. M., Hassan F. A., Flower R. J., Aly M. H., Senussi A., and Ebrahim E. S. 2014. Ancient Egyptian Pottery from the Subsurface Floodplain of the Saqqara-Memphis Area: Its Mineralogical and Geochemical Implications. Archaeometry 56(6): 987-1008.

https://doi.org/10.1111/arcm.12075

Hamzeh M., Mahmudy Gharaie M., Alizadeh Lahijani H., Moussavi Harami R., and Jamali M. 2017. Aeolian sediments deposited in Lake Hamoun; the proxy of frequency and severity of dust storms in Sistan since the late glacial. Journal of Stratigraphy and Sedimentology Researches 33(1): 1-24. (in Persian)

Hassan F. A., Hamdan M. A. 2008. The Faiyum Oasis-climate change and water management in ancient Egypt. In Traditional Water Techniques: Cultural heritage for a sustainable future. Henry Graphix. Cairo: 117-147.

Hejazizadeh Z., Javizadeh S. 2010. Introduction to Drought and Its Indices. SAMT. Tehran. (in Persian)

Hessari M. 2011. New Evidence of the Emergence of Complex Societies Discovered on the Central Iranian Plateau. Iranian Journal of Archaeological Studies 1(2): 35-48.

Hessari M., Ali-Yari A., and Akbari H. 2007. Stratification and Border Determination of the Archaeological Site, Shoghali, Pishva. In Archaeological Reports (7). Proceedings of the $9^{\text {th }}$ Annual Symposium on Archaeological Research in Iran. Archaeological Research Center, Cultural Heritage, Handicrafts and Tourism Organization. Tehran: 131-164. (in Persian)

Jassim R. Z., Al-Rawi Y. T., and Habib H. R. 2007. Holocene Aridification in Central Iraq. Iraqi Bulletin of Geology and Mining 3(1): 1-9.

Jones M., Djamali M., Stevens L., Heyvaert V., Askari H., Norolahie D., and Weeks L. 2013. Mid Holocene environmental and climatic change in Iran. In C. A. Petrie (ed.), Ancient Iran and Its Neighbours: Local Developments and Long-range Interactions in the $4^{\text {th }}$ Millennium $B C$. British Institute for Persian Studies and Oxbow Books. Oxford: 26-35.

Kaboli M. 1999. Archeological surveys in Qom River. Archaeological Research Center. Cultural Heritage, Handicrafts and Tourism Organization. Tehran. (in Persian) 
Kuzucuoğlu C., Dörfler W., Kunesch S., and Goupille F. 2011. Mid-to Late-Holocene climate change in central Turkey: The Tecer Lake record. The Holocene 21(1): 173188. https://doi.org/10.1177/0959683610384163

Lemcke G., Sturm M. 1997. $\delta^{180}$ and trace element measurements as proxy for the reconstruction of climate changes at Lake Van (Turkey): preliminary results. In H. N. Dalfes, G. Kukla, and H. Weiss (eds.), Third millennium BC climate change and old world collapse. Springer Science and Business Media. Berlin: 653-678.

Madani K. 2014. Water management in Iran: what is causing the looming crisis? Journal of environmental studies and sciences 4(4): 315-328.

https://doi.org/10.1007/s13412-014-0182-Z

Maghsoudi M., Jafari Bagloo M., and Rahimi 0. 2014. Sedimentary Evidences of Climate Change in the Lake Zeribar during the Holocene. Natural Geographic Research 46(1): 43-58. (in Persian)

Maghsoudi M., Mohammad Nejad V. 2011. Geomorphology of Alluvial Fans. University of Tehran. Tehran. (in Persian)

Majidzadeh Y. 2010. Excavations at ancient site of $\mathrm{Oz}$ beki. Directorate of Cultural Heritage, Handicrafts and Tourism of Tehran Province. Tehran. (in Persian)

Marks L., Salem A., Welc F., Nitychoruk J., Chen Z., Blaauw M., Zalat A., Majecka A., Szymanek M., Chodyka M., and Tołoczko-Pasek A. 2018. Holocene lake sediments from the Faiyum Oasis in Egypt: a record of environmental and climate change. Boreas 47(1): 62-79.

https://doi.org/10.1111/bor.12251

Mayewski P. A., Rohling E. E., Stager J. C., Karlén W., Maasch K. A., Meeker L. D., Meyerson E. A., Gasse, F., van Kreveld S., Holmgren K., and Lee-Thorp J. 2004. Holocene climate variability. Quaternary research 62(3): 243-255. https://doi.org/10.1016/j.yqres.2004.07.001

Mayewski P. A., Meeker L. D., Twickler M. S., Whitlow S., Yang Q., Lyons W. B., and Prentice M. 1997. Major features and forcing of high-latitude northern hemisphere atmospheric circulation using 110000 -year-long glaciochemical series. Journal of Geophysical Research: Oceans 102(C12): 26345-26366.

https://doi.org/10.1029/96JC03365

McMichael A. J. 2012. Insights from past millennia into climatic impacts on human health and survival. Proceedings of the National Academy of Sciences 109(13): 47304737. https://doi.org/10.1073/pnas.1120177109

McMichael A. J., Woodruff R. E., and Hales S. 2006. Climate change and human health: present and future risks.
The Lancet 367(9513): 859-869.

https://doi.org/10.1016/S0140-6736(06)68079-3

Migowski C., Stein M., Prasad S., Agnon A., and Negendank J. F. W. 2006. Holocene climate variability and cultural evolution in the Near East from the Dead Sea sedimentary record. Quaternary Research 66(3): 421-431.

Mosadeghi F. 2001. Research Report on the Investigation and Identification of Historic and Historical Cultural Works of the Shahriar Governorate. Tehran Province Cultural Heritage. Tehran. (in Persian)

Palumbo G. 2001. The Early Bronze IV. In B. MacDonald, R. Bienkowski (eds.), The Archaeology of Jordan. Academic Press. Sheffield: 233-269.

Petrie C. A., Weeks L. 2018. The Iranian Plateau and the Indus River Basin. In E. Chiotis (ed.), Climate Changes in the Holocene: Impacts and Human Adaptation. CRC Press. Boca Raton: 293-325.

Philander S. G. 1989. El Niño, La Niña, and the southern oscillation. Vol. 46. Academic press. New York.

Pitulko V. V., Nikolsky P. A., Girya E. Y., Basilyan A. E., Tumskoy V. E., Koulakov S. A., Astakhov, S. N., Pavlova E. Y., and Anisimov M. A. 2004. The Yana RHS site: humans in the Arctic before the last glacial maximum. Science 303(5654): 52-56.

https://doi.org/10.1126/science.1085219

Pollard A. M., Nashli H. F., Davoudi H., Sarlak S., Helwing B., and Saeidi F. 2013. A new radiocarbon chronology for the North Central Plateau of Iran from the Late Neolithic to the Iron Age. Archäologische Mitteilungen aus Iran und Turan 45: 27-50.

Pollard A. M., Davoudi H., Mostafapour I., Valipour H. R., and Fazeli Nashli H. 2012. A New radiocarbon chronology for the late Neolithic to Iron Age in the Qazvin plain, Iran. The International Journal of Humanities 19(3): 110-151.

Possehl G. L. 2000. The drying up of the Sarasvati: Environmental disruption in South Asian prehistory. In R. M. Reycraft, G. Bawden (eds.), Environmental disaster and the archaeology of human response. Maxwell Museum of Anthropology. Albuquerque: 63-74.

1997a. Climate and the eclipse of the ancient cities of the Indus. In H. N. Dalfes, G. Kukla, and H. Weiss (eds.), Third millennium BC climate change and old world collapse. Springer Science and Business Media. Berlin. Heidelberg: 193-243.

1997b. The transformation of the Indus civilization. Journal of World Prehistory 11(4): 425-472. https://doi.org/10.1007/BF02220556 
Prentice R. 2009. Cultural Responses to Climate Change in the Holocene. Anthós 1(1): 1-13.

https://doi.org/10.15760/anthos.2009.41

Railsback L. B., Liang F., Brook G. A., Voarintsoa N. R. G., Sletten H. R., Marais E., Hardt B., Cheng H., and Edwards R. L. 2018. The timing, two-pulsed nature, and variable climatic expression of the $4.2 \mathrm{ka}$ event: A review and new high-resolution stalagmite data from Namibia. Quaternary Science Reviews 186: 78-90.

https://doi.org/10.1016/j.quascirev.2018.02.015

Roebuck C. 1966. The world of ancient times. C. Scribner's Sons. New York.

Rosén P., Segerström U., Eriksson L., Renberg I., and Birks H. J. B. 2001. Holocene climatic change reconstructed from diatoms, chironomids, pollen and near-infrared spectroscopy at an alpine lake (Sjuodjijaure) in northern Sweden. The Holocene 11(5): 551-562.

https://doi.org/10.1191/095968301680223503

Rychagov G. I. 1997. Holocene oscillations of the Caspian Sea, and forecasts based on palaeogeographical reconstructions. Quaternary International 41: 167-172. https://doi.org/10.1016/S1040-6182(96)00049-3

Ryholt K. S., Bülow-Jacobsen A. 1997. The Political Situation in Egypt during the Second Intermediate Period, $c$. 1800-1550 BC. Museum Tusculanum Press. Copenhagen.

Sadat Hoseini Z., Khaledi S., and Naderi Bani A. 2017. Paleoclimate reconstruction and vegetation dynamic during Pleistocene and Holocene based on palynology at Dasht E Arzhan wetland Fars Southwest Iran. Journal of Climate Research 1395(27): 87-98.

Safaeirad R., Azizi G., Mohammadi H., Alizadeh Lahijan H. 2014. Reconstruction of Closures of Holocene and PostPleistosene in the Middle Zagros Area Using the Pseudodynamic Evidence of Hasheylan Wetlands. Geography and environmental hazards 11: 19-19. (in Persian)

Sarlak S. 2011. The archaeology and history of Qom: Archaeological Excavations in Gholi Darvish, JamkaranQom. Shakhes publication. Qom. (in Persian)

Schmidt E. F., Kimball F. 1937. Excavations at Tepe Hissar, Damghan. University of Pennsylvania Museum of Archaeology and Anthropology. University of Pennsylvania Press. Philadelphia.

Schweitzer M. D., Calzadilla A. S., Salamo 0., Sharifi A., Kumar N., Holt G., Campos M., and Mirsaeidi M. 2018. Lung health in era of climate change and dust storms. Environmental research 163: 36-42.

https://doi.org/10.1016/j.envres.2018.02.001
Sen S. 1941. Old Persian Inscriptions of the Achaemenian Emperors. University of Calcutta. Calcuta.

Shaikh Baikloo Islam B. 2018. Impact of climatic changes of the Mid-Holocene era on the cultures of sixth to fourth millennium BC in the north of central Iran. Unpublished PhD Dissertation. Islamic Azad University, Science and Research Branch. Tehran. (in Persian)

Shaikh Baikloo Islam B., Chaychi Amirkhiz A., and Valipour H. R. in press. Study of the impacts of the Middle Holocene Climatic Oscillations on Sialk III Societies in the Center of Iranian Plateau Based on Environmental Sedimentology of Mafin Abad, Islamshahr. Archaeological Studies. (in Persian)

Shaikh Baikloo Islam B., Chaychi Amirkhiz A., and Valipour H. R. 2016. On the Possible Correlation between the Collapse of Sialk IV and Climatological Events during the Middle-Late Holocene. Iranian Journal of Archaeological Studies 6(1): 42-52. https://doi.org/10.22111/IJAS.2016.3770

Sharifi A., Pourmand A., Canuel E. A., Ferer-Tyler E., Peterson L. C., Aichner B., Feakins S. J., Daryaee T., Djamali M., Beni A. N., and Lahijani H. A. 2015. Abrupt climate variability since the last deglaciation based on a high-resolution, multi-proxy peat record from NW Iran: The hand that rocked the Cradle of Civilization? Quaternary Science Reviews 123: 215-230.

https://doi.org/10.1016/j.quascirev.2015.07.006

Sirocko F., Sarnthein M., Erlenkeuser H., Lange H., Arnold M., and Duplessy J. C. 1993. Century-scale events in monsoonal climate over the past 24000 years. Nature 364 (6435): 322. https://doi.org/10.1038/364322a0

Staubwasser M., Weiss H. 2006. Holocene climate and cultural evolution in late prehistoric-early historic West Asia. Quaternary Research 66(3): 372-387.

https://doi.org/10.1016/j.yqres.2006.09.001

Staubwasser M., Sirocko F., Grootes P. M., and Segl M. 2003. Climate change at the $4.2 \mathrm{ka} \mathrm{BP}$ termination of the Indus valley civilization and Holocene South Asian monsoon variability. Geophysical Research Letters 30(8): 1425. https://doi.org/10.1029/2002GL016822

Stevens L. R., Ito E., Schwalb A., and Wright Jr. H. E. 2006. Timing of atmospheric precipitation in the Zagros Mountains inferred from a multi-proxy record from Lake Mirabad, Iran. Quaternary research 66(3): 494-500. https://doi.org/10.1016/j.yqres.2006.06.008

Stevens L. R., Wright Jr H. E., and Ito E. 2001. Proposed changes in seasonality of climate during the Lateglacial and Holocene at Lake Zeribar, Iran. The Holocene 11(6): 747-755. https://doi.org/10.1191/09596830195762 
Thompson L. G., Mosley-Thompson E., Brecher H., Davis M., León B., Les D., Lin P. N., Mashiotta T., and Mountain K. 2006. Abrupt tropical climate change: Past and present. Proceedings of the National Academy of Sciences 103 (28): $10536-10543$.

https://doi.org/10.1073/pnas.0603900103

Trombley J., Chalupka S., and Anderko L. 2017. Climate change and mental health. The American Journal of Nursing 117(4): 44-52. https://journals.lww.com/ajnon line/Abstract/2017/04000/Climate_Change_and_Mental_ Health.28.aspx

Vaezi A., Ghazban F., Tavakoli V., Routh J., Beni A. N., Bianchi T. S., Curtis J. H., and Kylin H. 2018. A Late Pleistocene-Holocene multi-proxy record of climate variability in the Jazmurian playa, southeastern Iran. Palaeogeography, Palaeoclimatology, Palaeoecology 514: 754-767. https://doi.org/10.1016/j.palaeo.2018.09.026

Valipour H. R. 2006. Preliminary Report of Excavation at Tepe Shizar, First Season. Unpublished. Archaeological Research Center. Tehran. (in Persian)

Vatandoust A., Parzinger A., Helwing B., and Thornton C. P. 2011. Early Mining and Metallurgy on the Western Central Iranian Plateau, the First Five Years of Work. Philipp von Zabern. Mainz.

Wasylikowa K., Witkowski A., Walanus A., Hutorowicz A., Alexandrowicz S. W., and Langer J. J. 2006. Palaeolimnology of Lake Zeribar, Iran, and its climatic implications. Quaternary Research 66(3): 477-493.

https://doi.org/10.1016/j.yqres.2006.06.006

Weiss H. (ed.) 2017. Megadrought and collapse: from early agriculture to Angkor. Oxford University Press. Oxford.

2016. Global megadrought, societal collapse and resilience at 4.2-3.9 ka BP across the Mediterranean and west Asia. Past Global Changes 24(2): 62-63.

https://doi.org/10.22498/pages.24.2.62

Weiss H., Courty M. A., Wetterstrom W., Guichard F., Senior L., Meadow R., and Curnow A. 1993. The genesis and collapse of third millennium north Mesopotamian civili- zation. Science 261(5124): 995-1004.

https://science.sciencemag.org/content/261/5124/995

Wick L., Lemcke G., and Sturm M. 2003. Evidence of Lateglacial and Holocene climatic change and human impact in eastern Anatolia: high-resolution pollen, charcoal, isotopic and geochemical records from the laminated sediments of Lake Van, Turkey. The Holocene 13(5): 665675. https://doi.org/10.1191/0959683603hl653rp

Wilhite D. A. 1992. Drought. In W. A. Nierenberg (ed.), Encyclopedia of Earth System Science. Vol. 2. Academic Press. San Diego: 81-92.

Wilhite D. A. Glantz M. H. 1985. Understanding: the drought phenomenon: the role of definitions. Water international 10(3): 111-120.

http://digitalcommons.unl.edu/droughtfacpub/20

Voigt M. M., Dyson R. H. J. 1992. Chronology of Iran, ca. 8000-2000 BC. In R. W Ehrich (ed.), Chronologies of Old World Archaeology. University of Chicago Press. Chicago: (I) $122-178$; (II) 25-53.

Xu D., Lu H., Chu G., Wu N., Shen C., Wang C., and Mao L. 2014. 500-year climate cycles stacking of recent centennial warming documented in an East Asian pollen record. Scientific reports $4: 3611$.

https://doi.org/10.1038/srep03611

Yousefi Zoshk R., Mohammadi K. B., Zeighami M., Baghizadeh S., Golcheh M., Ahmadpour H., Miri J., Nezhad M. G., Nezari N., Mohammadi N. B., and Alimadadi E. 2015. Meymanat Abad Tepe: An important Site in Late Fourth Millennium BC in Iranian Central Plateau. Archaeology 4(1): 13-21. http://article.sapub.org/10.5923.j.archaeolo gy.20150401.02.html

Yousefi Zoshk R. 2011. Archaeological Report of Excavations at the Chaltassian Site. Unpublished report. Archaeological Research Center. Tehran. (in Persian)

Zerboni A., Biagetti S., Lancelotti C., and Madella M. 2016. The end of the Holocene Humid Period in the central Sahara and Thar deserts: societal collapses or new opportunities? PAGES Magazine 24(2): 60-61.

https://doi.org/10.22498/pages.24.2.60 